\title{
Sulfur Fixation by Chemically Modified Red Mud Samples Containing Inorganic Additives: A Parametric Study
}

\author{
Yang Liu, Yang Li, Feng-shan Zhou, Ying-mo Hu, and Yi-he Zhang \\ Beijing Key Laboratory of Materials Utilization of Nonmetallic Minerals and Solid Wastes, National Laboratory of Mineral Materials, \\ School of Materials Science and Technology, China University of Geosciences (Beijing), Beijing 100083, China
}

Correspondence should be addressed to Feng-shan Zhou; zhoufs@cugb.edu.cn

Received 23 January 2016; Revised 8 June 2016; Accepted 17 July 2016

Academic Editor: Santiago Garcia-Granda

Copyright (C) 2016 Yang Liu et al. This is an open access article distributed under the Creative Commons Attribution License, which permits unrestricted use, distribution, and reproduction in any medium, provided the original work is properly cited.

\begin{abstract}
Sulfur retention ability of Bayer red mud from alumina plant was investigated. Bayer red mud modified by fusel salt and waste mother liquor of sodium ferrocyanide as the main sulfur fixation agent and the calcium based natural mineral materials as servicing additives; the experimental results showed the following: (1) Through $10 \mathrm{wt} \%$ waste mother liquor of sodium ferrocyanide modifying Bayer red mud, sulfur fixation rate can increase by $13 \mathrm{wt} \%$. (2) Magnesium oxide can obviously improve the sulfur fixation performance of Bayer red mud and up to a maximum sulfur fixation rate of $47 \mathrm{wt} \%$ at adding $1 \mathrm{wt} \%$ magnesium oxide. (3) Dolomite enhanced the sulfur fixation performances with the sulfur fixation rate of $68 \mathrm{wt} \%$ in optimized condition. (4) Vermiculite dust reduced sulfur dioxide during the fixed-sulfur process of modified Bayer red mud, and the desulphurization ration could reach up to a maximum $76 \mathrm{wt} \%$ at $950^{\circ} \mathrm{C}$. (5) An advanced three-component sulfur fixation agent was investigated, in which the optimized mass ratio of modified Bayer red mud, dolomite, and vermiculite dust was $70: 28: 2$ in order, and its sulfur fixation efficiency has reached to a maximum $87 \mathrm{wt} \%$ under its $20 \mathrm{wt} \%$ dosage in the coal.
\end{abstract}

\section{Introduction}

Since the 1980s, with the rapid development of China's economy, the annual consumption of coal has been increasing by a large margin and China has become the largest producer and consumer of coal [1]. The main pollution of China is derived from emissions of $\mathrm{SO}_{2}$ and dust caused by coal combustion. Therefore, the control of $\mathrm{SO}_{2}$ emitted from industrial coal-fired boilers has great significance for air pollution control in our country [2]. Desulfurization technology is the main method to reduce $\mathrm{SO}_{2}$ pollution [3]. At present, the commonly used desulphurization technology includes desulfurization before combustion, sulfur fixation during combustion, and flue gas desulfurization [4]. Developing a new type of sulfur fixing agents has become the most valuable industrial desulfurization technical way in coal combustion process [5]. At present, the mainly used sulfur-fixing agents at home and abroad include calcium-based, magnesium-based, sodium-based, and potassium-based sulfur-fixing agents [69]. Traditional calcium-based sulfur-fixing agent (limestone, dolomite, etc.) generally showed the disadvantages of low calcium utilization rate and low sulfur fixation rate at high temperature [10].

In recent years, many domestic and foreign researchers found that the sulfur-fixing efficiency of coal combustion could be improved by modifying the fixing agents using sodium chloride [11], ethanol, and acetic acid [12] or adding $\mathrm{Fe}_{2} \mathrm{O}_{3}, \mathrm{SiO}_{2}, \mathrm{Al}_{2} \mathrm{O}_{3}$, and $\mathrm{Na}_{2} \mathrm{CO}_{3}$ [13-18] to the sulfur-fixing agents.

In addition to the researches of sulfur-fixing additive, some industrial solid waste is also used as desulfurization agents such as Carbide slag, black liquor of papermaking, and red mud [19-26]. Bayer red mud is an industrial solid waste with high alkalinity and environmental impact, which is discharged during the process of $\mathrm{Al}_{2} \mathrm{O}_{3}$ extraction from bauxite in alumina plant. Disposal of Bayer red mud occupies large areas of productive land, and it is harmful to the environment due to its high alkalinity, heavy metals, and sometimes radioactivity [27-29]. Red mud is mainly composed of fine particles including $\mathrm{Al}_{2} \mathrm{O}_{3}, \mathrm{Fe}_{2} \mathrm{O}_{3}, \mathrm{CaO}$, $\mathrm{MgO}$, and $\mathrm{Na}_{2} \mathrm{O}[19,20]$. Owing to its high alkalinity and chemical properties, Bayer red mud could be used as a kind 
TABLE 1: Chemical composition of Bayer red mud in the present work.

\begin{tabular}{lcccccccc}
\hline Components & $\mathrm{Al}_{2} \mathrm{O}_{3}$ & $\mathrm{CaO}$ & $\mathrm{SiO}_{2}$ & $\mathrm{Fe}_{2} \mathrm{O}_{3}$ & $\mathrm{Na}_{2} \mathrm{O}$ & $\mathrm{MgO}$ & Water & Loss \\
\hline Content/wt $\%$ & 24.35 & 19.96 & 18.12 & 7.79 & 5.54 & 1.47 & 0.87 & 14.25 \\
\hline
\end{tabular}

of sulfur-fixing agent. This not only opens up a new way for the utilization of red mud but also finds a cheap and efficient sulfur-fixing agent for the coal industry.

In recent years, many domestic and foreign scholars focused their research on red mud slurry for flue gas desulfurization [21, 22]. But the red mud slurry is easy to harden and not conducive for long time use [23]. By adding natural minerals to Bayer red mud, a high performance synergistic sulfur-fixing agent was developed for sulfur fixation during coal combustion in the present work. According to the sulfurfixing product of sulfur-fixing agent, we will continue to study the preparation of oilfield waste drilling fluid treatment agent using the sulfur-fixing product, which will truly achieve high value-added and clean utilization of red mud.

\section{Materials and Methods}

\subsection{Materials}

Raw Coal. Raw coal came from Zouping Weimian Corporation (Shandong, China). The total sulfur content in the coal sample was determined by Eschka method [30]. $0.2 \mathrm{~g}$ coal (200 mesh) was mixed with Eschka reagent and burned. The sulfur in the coal reacted with Eschka reagent to produce sulfate. Then, sulfate ions $\left(\mathrm{SO}_{4}{ }^{2-}\right)$ reacted with barium ions $\left(\mathrm{Ba}^{2+}\right)$ to produce barium sulfate $\left(\mathrm{BaSO}_{4}\right)$. The total sulfur content was calculated according to the produced weight of $\mathrm{BaSO}_{4}$. Experimental results showed that the total sulfur content of the raw coal was $1.685 \mathrm{wt} \%$. According to the classification standard of sulfur coal [31], the raw coal belongs to the middle sulfur coal.

Bayer Red Mud. The red mud in the present work in the form of dried clay was obtained from Zhengzhou Great Wall Alumina Corporation (Henan Province, China). Table 1 shows the component contents of the red mud. The XRD pattern and its particle size distribution of the red mud sample are shown in Figures 1 and 2. The particle size of the red mud was in the range of $0.1-500 \mathrm{~mm}$ (generally finer than 200 mesh after drying and grinding). The mineral compositions of the Bayer red mud were very complicated [32], but the content of $\mathrm{Al}_{2} \mathrm{O}_{3}$ and $\mathrm{SiO}_{2}$ was relatively high with $24.35 \mathrm{wt} \%$ and $18.12 \mathrm{wt} \%$.

Modification Agents. Modification agents were the byproduct of yellow blood sodium (sodium ferrocyanide) solution from Hebei Chengxin Co., Ltd. (Hebei, China), and fusel alcohol salts from Changchun Dacheng Industry Company (Jilin, China). The chemical composition was shown in Tables 2 and 3.

Sulfur Fixation Additives. Magnesium oxide ( $\mathrm{MgO}$, industrial grade, purity more than $95 \mathrm{wt} \%$ ) was obtained from Beijing

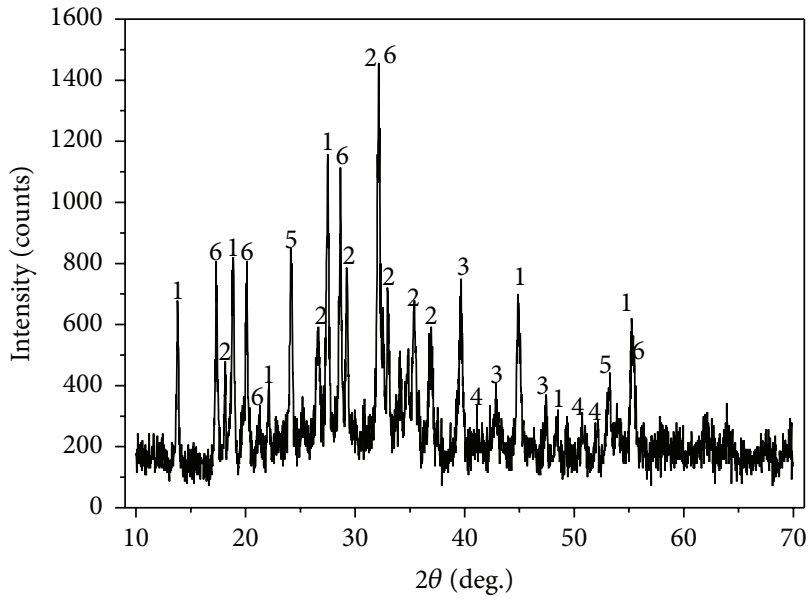
(1) $\mathrm{Na}_{2} \mathrm{O} \cdot \mathrm{Al}_{2} \mathrm{O}_{3} \cdot 2 \mathrm{SiO}_{2}$
(2) $\mathrm{CaSi}_{2} \mathrm{O}_{5} \cdot 2 \mathrm{H}_{2} \mathrm{O}$
(4) $\mathrm{Al}(\mathrm{OH})_{3}$
(3) $\mathrm{CaCO}_{3}$
(5) $\mathrm{Fe}_{2} \mathrm{O}_{3}$
(6) $3 \mathrm{CaO} \cdot \mathrm{Al}_{2} \mathrm{O}_{3} \cdot \mathrm{SiO}_{2} \cdot 4 \mathrm{H}_{2} \mathrm{O}$

FIGURE 1: XRD of Bayer red mud in the present work.

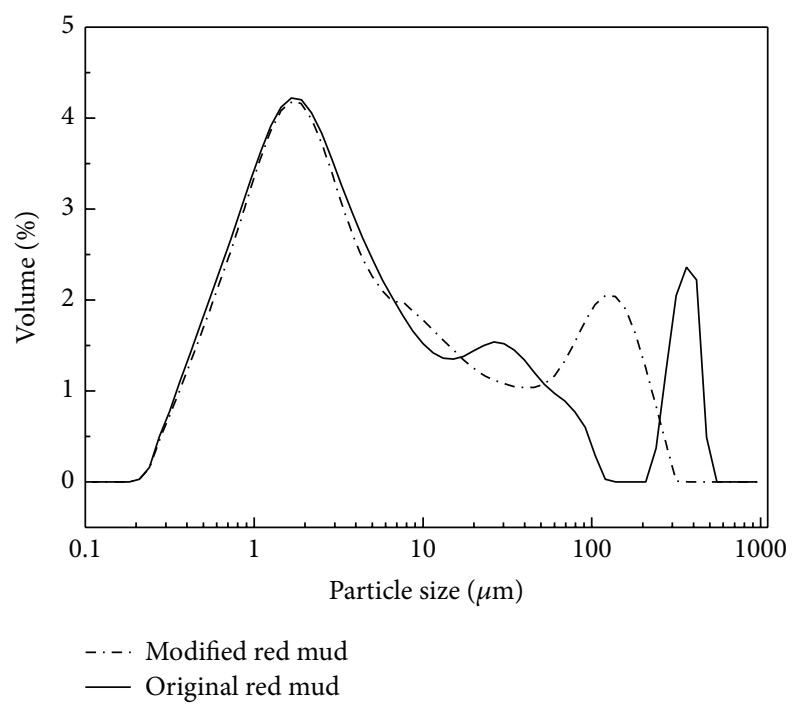

FIgUre 2: Particle size distribution of Bayer red mud in the present work.

Chemical Plant. The natural mineral materials brucite and dolomite were obtained from Dandong Yilong Gaoke New Material Co., Ltd. (Liaoning, China); both of their particle sizes were in the range of 800-1000 mesh.

Sulfur Fixation Promoter. Byproduct dust of vermiculite obtained from Hebei Chenxiang Mineral Materials Research Institute (Hebei, China) has been designated as promoter; its particle size was in the range of 60-200 mesh. 
TABLE 2: Chemical composition of waste mother liquor of sodium ferrocyanide.

\begin{tabular}{lcccc}
\hline Components & $\mathrm{Na}_{2} \mathrm{Fe}(\mathrm{CN})_{6}$ & $\mathrm{HCOONa}$ & $\mathrm{Na}_{2} \mathrm{CO}_{3}$ & Water \\
\hline Content/wt $\%$ & 5.29 & 39.83 & 5.27 & 49.31 \\
\hline
\end{tabular}

2.2. Laboratory Instruments. The $\mathrm{pH}$ of red mud suspension in the reaction process was measured by $\mathrm{pH} 500$ meter. The chemical analytical methods of $\mathrm{Al}_{2} \mathrm{O}_{3}, \mathrm{CaO}$, and $\mathrm{MgO}$ were Karl Fischer titration, $\mathrm{SiO}_{2}$ by gravimetry, and $\mathrm{Fe}_{2} \mathrm{O}_{3}$ by colorimetry and $\mathrm{K}_{2} \mathrm{O} / \mathrm{Na}_{2} \mathrm{O}$ was determined by FP640 Flame Photometer. The XRD patterns of the samples were determined by $\mathrm{X}$-ray diffractometer with a $\mathrm{Cu} \mathrm{K} \alpha$ $(0.15418 \mathrm{~nm})$ radiation source in a $2 \theta$ range of $10^{\circ}-70^{\circ}$ at a scanning rate of $2^{\circ} \mathrm{min}^{-1}$. The morphologies of red mud were analyzed by Hitachi S- 4800 high resolution ice emission scanning electron microscopy (SEM) [33].

Both of the SK-G10123K Tube furnace and the SK-G18123 Muffle furnace were purchased from Zhonghuan Experiment Electric Furnace Co., Ltd. (Tianjin, China). Heating rate of the SK-G10123K Tube furnace was $5^{\circ} \mathrm{C} / \mathrm{min}$ at below $500^{\circ} \mathrm{C}$, $10^{\circ} \mathrm{C} / \mathrm{min}$ at $500-800^{\circ} \mathrm{C}, 5^{\circ} \mathrm{C} / \mathrm{min}$ at $800-1000^{\circ} \mathrm{C}$, and less than $2^{\circ} \mathrm{C} / \mathrm{min}$ at $1000-1200^{\circ} \mathrm{C}$. The length of its heating zone was $420 \mathrm{~mm}$, and its constant temperature zone was $200 \mathrm{~mm}$. Muffle furnace SK-G18123 Model with resistance wire heating was used; its heating process was $100^{\circ} \mathrm{C}$ to the maximum $1200^{\circ} \mathrm{C}$ in $40 \mathrm{~min}$.

\subsection{Experimental Methods}

2.3.1. Modification Experiment of Bayer Red Mud. The Bayer red mud was immersed in modification agents with certain concentration for $24 \mathrm{~h}$. Then, it was taken out and dried in an oven at constant temperature of $80^{\circ} \mathrm{C}$ for $12 \mathrm{~h}$. Finally, it was taken out from the oven, milled, and screened as a reserve. Particle size distribution of original and modified Bayer red mud is shown in Figure 2.

2.3.2. Sulfur Fixation Experiment. Sulfur fixation for combustion coal was carried out in the SK-G10123K Tube furnace. The furnace was heated to $950^{\circ} \mathrm{C}$ according to its heating rate procedure firstly; then the specified amount of coal sample mixed sulfur fixation agents beforehand was loaded in a combustion boat, the coal sample was pushed slowly to the furnace inside, and finally air was pumped into the furnace to make a full combustion of the coal sample.

2.3.3. The Calculation of Sulfur Fixation Rate and the Utilization Rate of Calcium. The sulfur content was determined by using chemical analysis method. The sulfur fixation efficiency $\eta$ (see (1)) and the utilization rate of calcium $\eta_{\mathrm{Ca}}$ (see (2)) $[26,34]$ were determined by testing the total sulfur content in coal ash and the coal sample:

$$
\eta=\frac{m_{2} \times S_{a d}}{m_{1} \times S_{t, a d}} \times 100 \%
$$

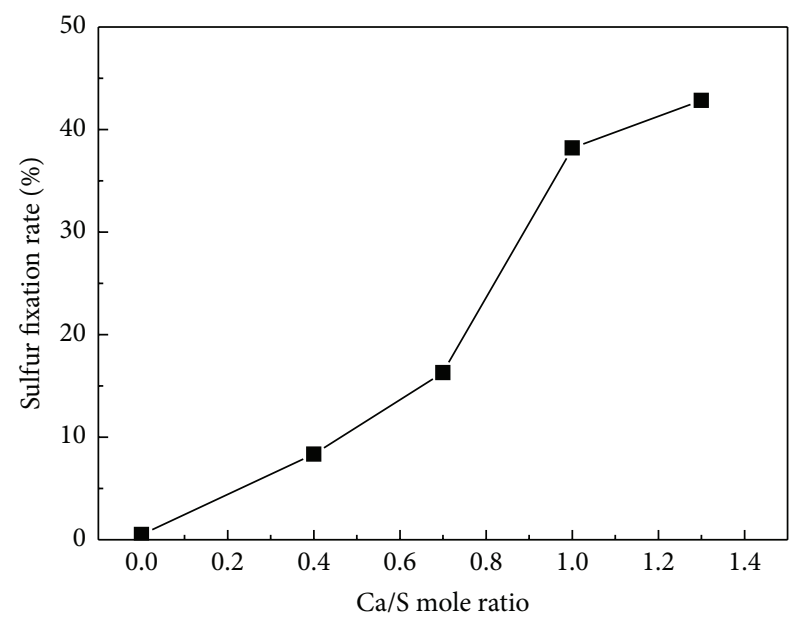

FIGURE 3: Influence of $\mathrm{Ca} / \mathrm{S}$ mole ratio on the sulfur fixation effect.

where $\eta$ is sulfur fixation efficiency; $m_{1}$ is experimental coal sample mass, $g ; m_{2}$ is total mass of ash after combustion, g; $S_{a d}$ is the sulfur content of ash, wt\%; and $S_{t, a d}$ is total sulfur content of experimental coal sample, wt $\%$. Consider

$$
\eta_{\mathrm{Ca}}=\frac{S_{a d} \times m_{2} \times 56}{32 \times M_{\mathrm{sfa}} \times W_{\mathrm{CaO}}} \times 100 \%,
$$

where $\eta_{\mathrm{Ca}}$ is utilization rate of calcium, wt $\% ; m_{2}$ is total mass of ash after combustion, $g ; S_{a d}$ is the sulfur content of ash, wt $\% ; M_{\text {sfa }}$ is the mass of adding sulfur fixation agent in the experiment, g; $W_{\mathrm{CaO}}$ is percentage content of $\mathrm{CaO}$ in the sulfur fixation agent, wt $\%$.

\section{Results and Discussion}

3.1. Influence of $\mathrm{Ca} / \mathrm{S}$ Mole Ratio on the Sulfur Fixation Effect. The $\mathrm{Ca} / \mathrm{S}$ mole ratio is one of the main factors that affect the sulfur fixation effect. Using Bayer red mud as the sulfur fixation agent, the influence of $\mathrm{Ca} / \mathrm{S}$ mole ratio on the sulfur fixation efficiency was studied. The results were shown in Figure 3.

Figure 3 indicated that the sulfur fixation rate increased with the increase of the $\mathrm{Ca} / \mathrm{S}$ mole ratio when Bayer red mud was used as sulfur fixation agent. However, the increase of the $\mathrm{Ca} / \mathrm{S}$ mole ratio would greatly increase the amount of sulfur fixation agent and reduce the heating rate of the coal. So, the doping content of Bayer red mud in the following experiment was optimized to be $10 \mathrm{wt} \%$ (the mole ratio of $\mathrm{Ca} / \mathrm{S}$ was 0.7 ).

\subsection{The Influence of Modification on the Sulfur Fixation Effect}

3.2.1. The Influence of Modification on the Sulfur Fixation Efficiency. Experimental results indicated that the maximum sulfur fixation efficiency of original Bayer red mud was only $42.83 \mathrm{wt} \%$ when the mass dosage of red mud as sulfur fixation agent was $20 \mathrm{wt} \%$ coal sample. Modification activation method was used to improve the sulfur fixation efficiency of red mud. Fusel salt and waste mother liquor of sodium ferrocyanide were used as modification agents. The influence 
TABLE 3: Chemical composition of the fusel salt.

\begin{tabular}{lccc}
\hline Components & $\begin{array}{c}\text { Ethylene glycol, propylene } \\
\text { glycol, butyl glycol, glycerin, } \\
\text { and so forth }\end{array}$ & $\begin{array}{c}\text { Salt mix (sodium formate, } \\
\text { sodium acetate and sodium } \\
\text { lactate, etc.) }\end{array}$ & $\begin{array}{c}\text { Polyether polyols (low } \\
\text { polymerization degree) }\end{array}$ \\
\hline Content/wt $\%$ & $35 \sim 45$ & $20 \sim 30$ & $25 \sim 35$ \\
\hline
\end{tabular}

TABLE 4: Effect of the fusel salt on sulfur fixation of modified Bayer red mud.

\begin{tabular}{|c|c|c|c|c|}
\hline Amount/wt\% & 0 & 10 & 30 & 50 \\
\hline Sulfur content in the residue/wt $\%$ & 0.667 & 0.877 & 1.171 & 1.684 \\
\hline Utilization rate of $\mathrm{Ca} / \mathrm{wt} \%$ & 10.20 & 16.20 & 21.95 & 31.61 \\
\hline Sulfur fixation rate/wt\% & 8.333 & 12.06 & 17.87 & 23.54 \\
\hline
\end{tabular}

TABLE 5: Effect of the waste mother liquor of sodium ferrocyanide on sulfur fixation of modified Bayer red mud.

\begin{tabular}{|c|c|c|c|c|}
\hline Amount/wt\% & 0 & 10 & 20 & 30 \\
\hline Sulfur content in the residue/wt $\%$ & 0.667 & 1.876 & 1.209 & 1.224 \\
\hline Utilization rate of $\mathrm{Ca} / \mathrm{wt} \%$ & 10.20 & 40.10 & 26.43 & 23.64 \\
\hline Sulfur fixation rate/wt\% & 8.333 & 29.85 & 20.58 & 18.48 \\
\hline
\end{tabular}

of different amount wt $\%$ of fusel salt and waste mother liquor of sodium ferrocyanide on the sulfur fixation efficiency of Bayer red mud was studied.

The results of Tables 4 and 5 and Figure 4 indicated that the sulfur fixation efficiency could increase by 7 percentage points after the Bayer red mud was modified by $50 \mathrm{wt} \%$ fusel solution. Meanwhile, the utilization efficiency also increased from $22.02 \mathrm{wt} \%$ to $31.61 \mathrm{wt} \%$. But the red mud after fusel modification was not easy to be dried and crushed and the mixing was not uniform. For the $10 \mathrm{wt} \%$ sodium ferrocyanide modified Bayer red mud, the sulfur fixation efficiency could increase by 13 percentage points and the utilization efficiency increased to $40.10 \mathrm{wt} \%$.

3.2.2. The Influence of Modification on the Surface Morphology of Bayer Red Mud. The results of Scanning Electronic Micrography (SEM) indicated that the morphology of the Bayer red mud modified by fusel salt and sodium ferrocyanide changed after calcination at $950^{\circ} \mathrm{C}$ (Figure 5). Nonsignificant structural change was observed in the three samples in Figure 5, but the sodium ferrocyanide modified sample showed a relatively more change in the formation of porous structure. Agglomeration was still noticeable in unmodified and modified red mud. The particles of unmodified Bayer red mud agglomerated more seriously, which was not conducive to the diffusion of $\mathrm{SO}_{2}$ and the sulfur fixation reaction. In contrast, the secondary pore structure in the modified sample was beneficial to the diffusion of the gases and promoted the sulfur fixation reaction. It was possible that the specific surface area (SSA) and porosity increased the fixation degree. Figure 6 shows the secondary porous structure after sulfur fixation reaction of modified red mud; the SSA has indeed increased (Table 6). As predecessors had proposed that the influence of pore structure characteristics on their sulfur fixation performance was very important, little pores made a significant contribution to alkaline substance utilization
TABLE 6: Specific surface area (SSA) of modified Bayer red mud before and after sulfur fixation reaction.

\begin{tabular}{lc}
\hline Sample & $\begin{array}{c}\text { Specific surface } \\
\text { area } \\
\text { with BET } \\
\text { method }\left(\mathrm{m}^{2} / \mathrm{g}\right)\end{array}$ \\
\hline Original Bayer red mud & 14.100 \\
$\begin{array}{l}\text { Bayer red mud modified by } 50 \mathrm{wt} \% \text { fusel solution } \\
\text { Bayer red mud modified by } 10 \mathrm{wt} \% \text { sodium }\end{array}$ & 99.086 \\
$\begin{array}{l}\text { ferrocyanide solution } \\
\text { Sulfur fixation ashes formed at } 950^{\circ} \mathrm{C} \text { after the } \\
\text { sulfur fixation reaction of three-component sulfur } \\
\text { fixation agent SFG-2 }\end{array}$ & 142.300 \\
\hline
\end{tabular}

in the initial stage of reaction and at lower temperature, while bigger pores took effect in the later stage and at higher temperature. The more the pore in range of effective aperture, the better the sulfur fixation performance [35].

3.3. The Influence of Additives on the Sulfur Fixation Efficiency. Because single modified Bayer red mud showed lower sulfur fixation efficiency, it was necessary to add some additives to improve sulfur fixation efficiency. In this paper, the effects of additives of magnesium containing were mainly studied.

\subsubsection{The Influence of $\mathrm{MgO}$ on the Sulfur Fixation Efficiency.} $\mathrm{MgO}$ additives with doping content of $1 \mathrm{wt} \%, 2 \mathrm{wt} \%$, and $3 \mathrm{wt} \%$ were added together with Bayer red mud to the coal samples. Experimental results of Figures 7 and 8 indicated that $\mathrm{MgO}$ significantly improved the sulfur fixation efficiency of the combustion coal. With the increase of $\mathrm{MgO}$ doping content, the sulfur fixation efficiency showed a decreasing trend after the first increase. The sulfur fixation efficiency was optimized to be $46.56 \mathrm{wt} \%$ when the doping content of $\mathrm{MgO}$ was $1 \mathrm{wt} \%$. 


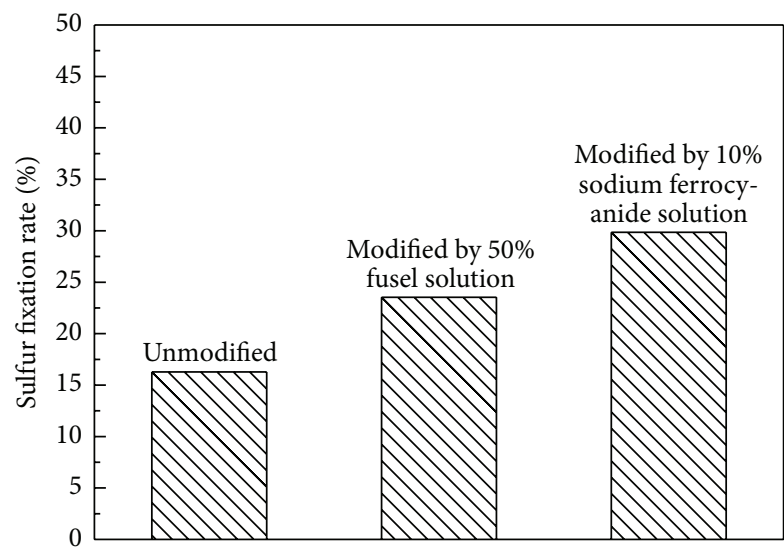

(a) Influence on the sulfur fixation rate

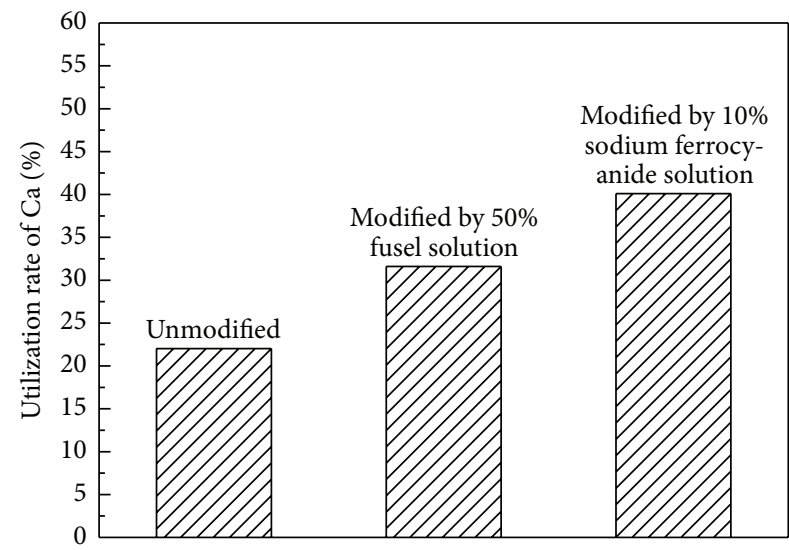

(b) Influence on the utilization rate of $\mathrm{Ca}$

FIgURE 4: Test results for modified Bayer red mud with different solutions.

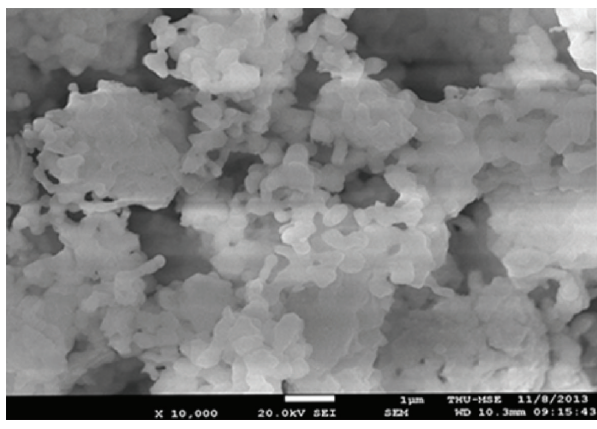

(a) Unmodified

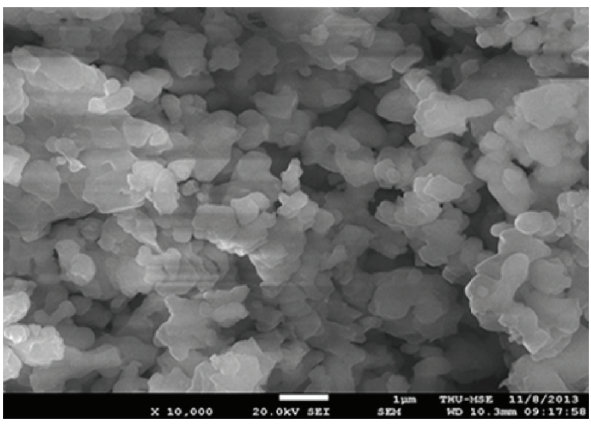

(b) Modified by $50 \mathrm{wt} \%$ fusel solution

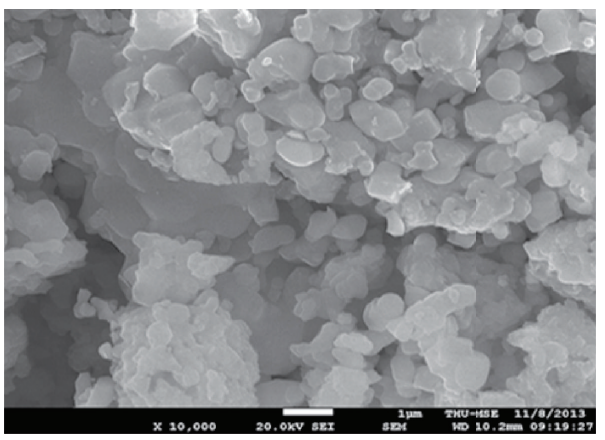

(c) Modified by $10 \mathrm{wt} \%$ sodium ferrocyanide solution

FIGURE 5: SEM photographs of modified Bayer red mud with different solutions.

During the sulfur fixation process, $\mathrm{SO}_{2}$ transformed into sulfate by reacting with $\mathrm{MgO}$. Meanwhile, $\mathrm{MgO}$ showed catalytic effects on sulfur fixation reaction for combustion of coal [36]. So the addition of $\mathrm{MgO}$ increased the sulfur fixation efficiency and improved the utilization rate of calcium (the highest utilization rate could reach $56.35 \mathrm{wt} \%$ ).

3.3.2. The Influence of Natural Mineral Materials Additives on the Sulfur Fixation Efficiency. Both of dolomite and brucite with doping content of $1 \mathrm{wt} \%, 2 \mathrm{wt} \%, 3 \mathrm{wt} \%$, and $4 \mathrm{wt} \%$ were added together with Bayer red mud to the coal samples.
The influence of dolomite and brucite on the sulfur fixation efficiency of the combustion coal was studied, respectively. The sulfur fixation efficiency increased with the addition of the two natural mineral materials (Figure 9). As an effective sulfur fixation mineral material, dolomite was better than brucite. The sulfur fixation efficiency was optimized to be $67.70 \mathrm{wt} \%$ when the doping content of dolomite was $4 \mathrm{wt} \%$. Meanwhile, the paper researched the effect of the mass ratio of brucite and dolomite $(4: 0,3: 1,2: 2,1: 3$, and $0: 4)$ on the sulfur fixation efficiency. According to Figure 10, the results showed that the efficiency of sulfur fixation was different under the same temperature but different dolomite/brucite 


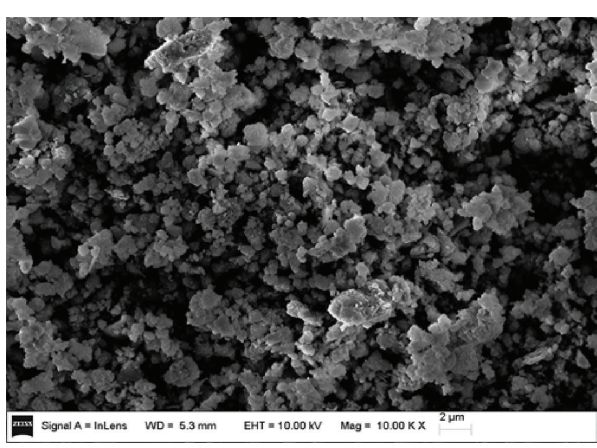

(a) $\mu \mathrm{m}$ scale

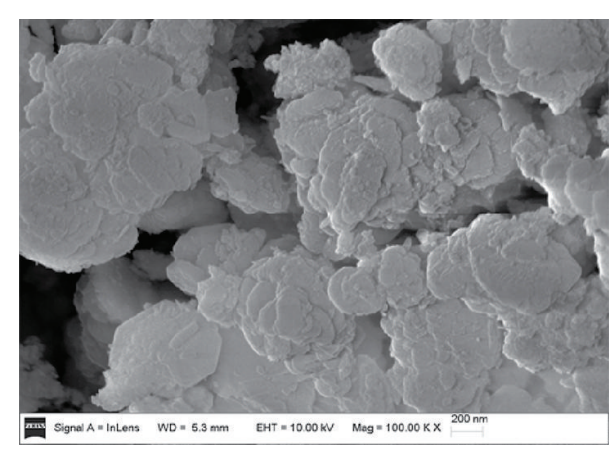

(b) nm scale

FIGURE 6: SEM photographs of secondary porous structure of sulfur fixation ashes formed after the sulfur fixation reaction of threecomponent sulfur fixation agent SFG-2.

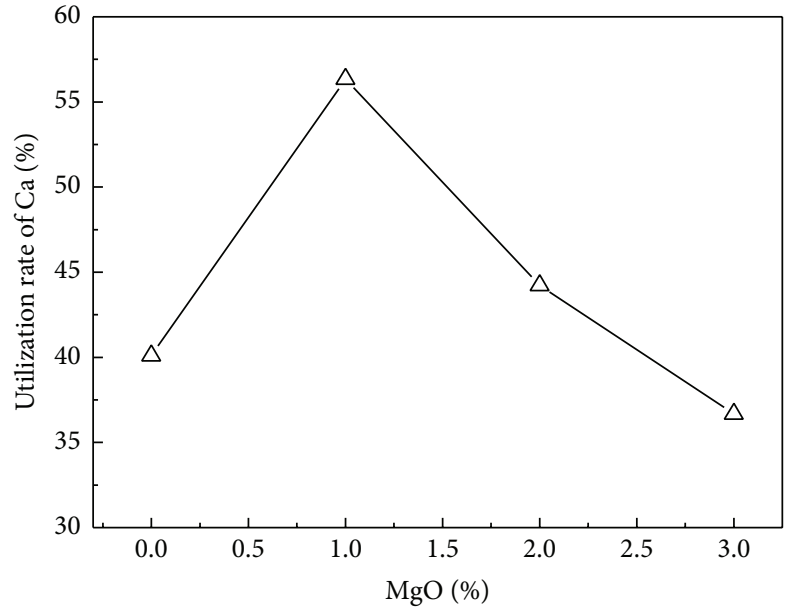

Figure 7: Effect of MgO on the utilization rate of Ca.

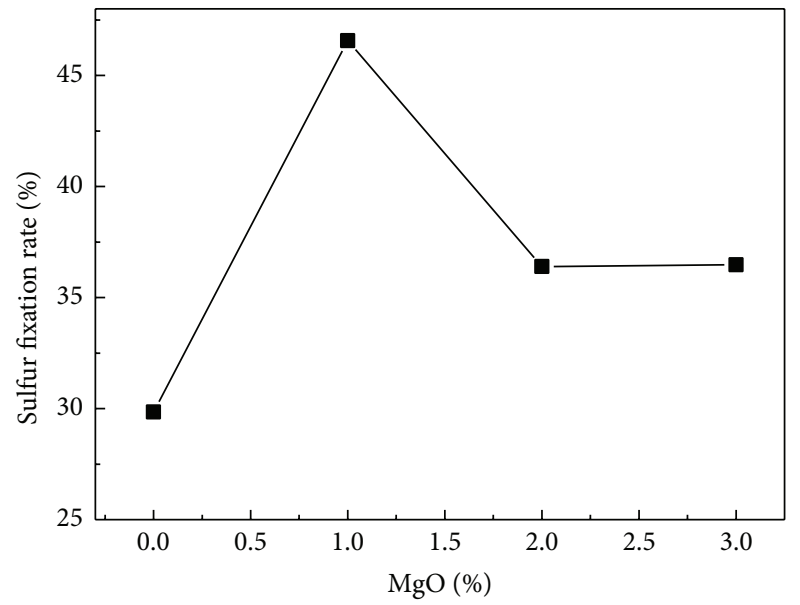

Figure 8: Effect of $\mathrm{MgO}$ on the sulfur fixation rate. ratio; with the dolomite increasing or brucite decreasing, the sulfur fixation increased, and the sulfur fixation efficiency was maximum $67.70 \mathrm{wt} \%$; with the only doping content of dolomite was $4 \mathrm{wt} \%$. According to above results, the paper selected dolomite as the additives of sulfur fixation agents and developed a new kind of sulfur-fixed agent named SFG-1 which is composed of modified Bayer red mud and dolomite with the mass ratio of $10: 4$ in order. At $950^{\circ} \mathrm{C}$, $\mathrm{CaO}$ and $\mathrm{MgO}$ derived from the decomposition of dolomite and brucite could react with $\mathrm{SO}_{2}$, showed a certain catalytic effect on sulfur fixation reaction, and improved the sulfur fixation efficiency. Besides, adding dolomite could improve pore structure of the red mud after high temperature calcination, accelerate the forming of high temperature stability of sulfide minerals, and restrain the decomposing of $\mathrm{CaSO}_{4}$ [19], which made the sulfur fixation efficiency improved. And the existence of dolomite can improve the pore structure of red mud in high temperature, which also enhanced the own desulfurization efficiency of Bayer red mud.

3.4. The Influence of Promoter on the Sulfur Fixation Efficiency. In order to further improve the sulfur fixation effect of combustion, the promoter added again by experimental design. Although the layered structure and dilatability of vermiculite promoted the inner oxidation extent of the coal combustion and enhanced the fixed-sulfur efficiency [37], vermiculite was difficult to crush because of its good toughness, so as to increase the cost of crushing. However, the dust from vermiculite industry was mainly composed of fine particles (160-200 mesh) and had high specific surface area. Using the vermiculite dust replacing normal industrial vermiculite as coal-burning sulfur-fixed promoter, the effect of different doping content of vermiculite dust $(0.1 \mathrm{wt} \%$, $0.2 \mathrm{wt} \%, 0.3 \mathrm{wt} \%$, and $0.4 \mathrm{wt} \%$ ) on fixed-sulfur efficiency was researched.

According to the experimental results (Figure 11), vermiculite dust could promote the fixed-sulfur efficiency. Experimental results showed that vermiculite dust played an important role in reducing $\mathrm{SO}_{2}$ during the fixed-sulfur process of modified Bayer red mud or SFG-1, and the desulphurization ration could reach up to maximum $76 \mathrm{wt} \%$ at $950^{\circ} \mathrm{C}$. The main reasons were that further inflating of vermiculite dust at $950^{\circ} \mathrm{C}$ could make the inner looser and promote the inner oxidation extent of the coal combustion, 


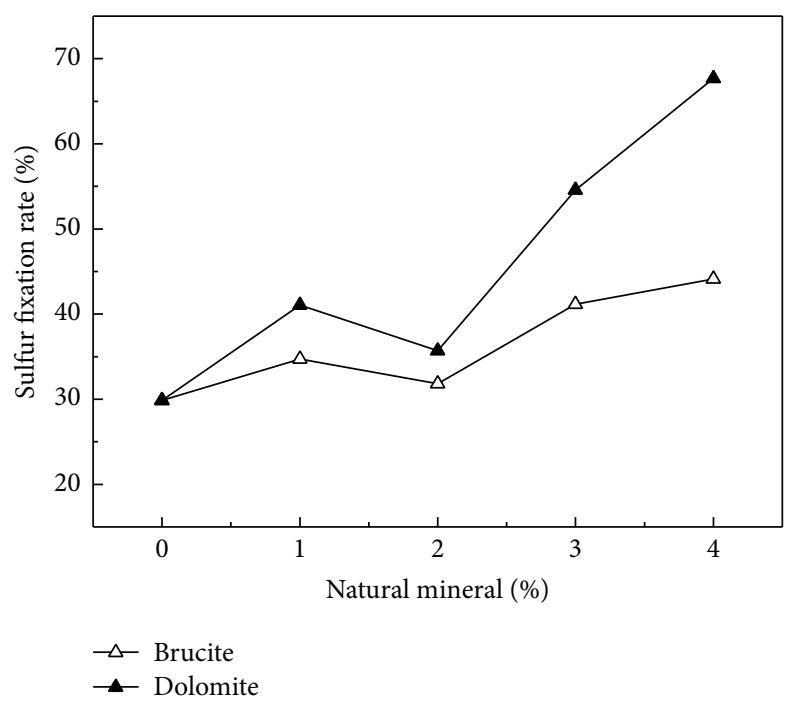

Figure 9: Effect of natural minerals on sulfur fixation rate.

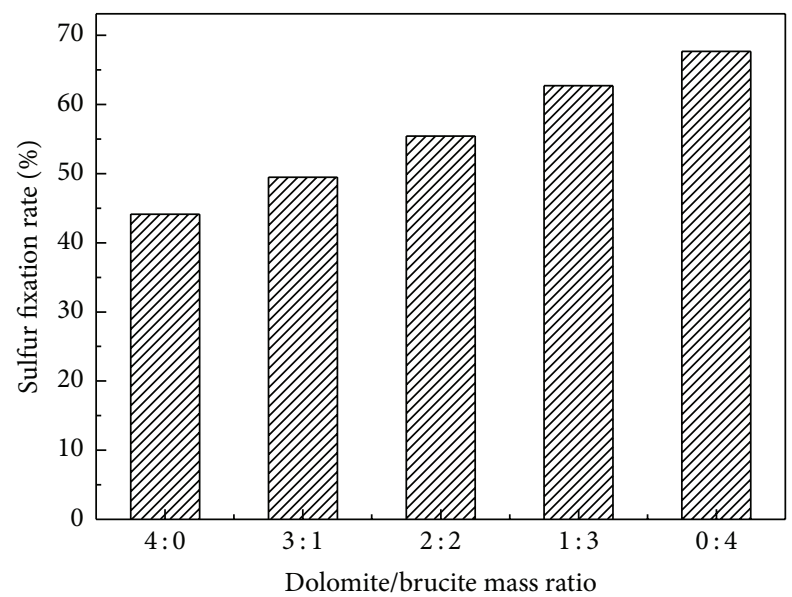

FIGURE 10: Effect of dolomite/brucite ratio on sulfur fixation rate.

which was advantageous to forming $\mathrm{CaSO}_{4}$ and restraining the decomposing of $\mathrm{CaSO}_{4}$ [38]. So, an advanced complex sulfur fixation agent named SFG-2 was made successfully by the experimental studies in which Bayer red mud was the main desulphurization composition, dolomite served as additives, vermiculite dust played the inflation role, and the optimized mass ratio of them in order was $70: 28: 2$.

\subsection{The Influence of SFG-2 on the Sulfur Fixation Efficiency.} The influence of SFG-2 content ranging in the coal from $10 \mathrm{wt} \%$ up to $25 \mathrm{wt} \%$ on the sulfur fixation efficiency was studied. Experimental results (Figure 12) showed that SFG2 achieved desulphurization ration maximum $87 \mathrm{wt} \%$ when the doping content of SFG-2 in the coal was up to $20 \mathrm{wt} \%$ (i.e., $\mathrm{Ca} / \mathrm{S}$ mole ratio was 1.3 ), and it may be inferred that the tricomponent composite SFG-2 was indeed an advanced desulphurization material.

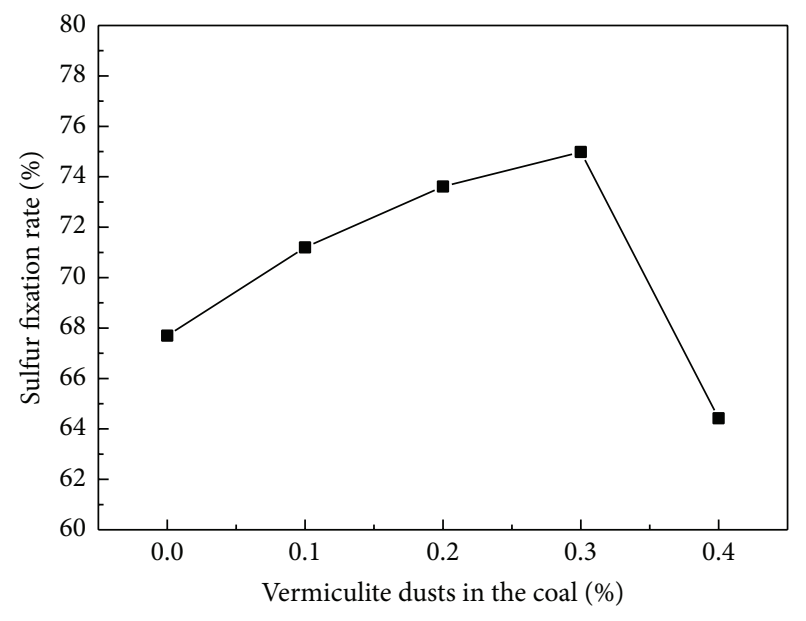

FIGURE 11: Effect of vermiculite dust on sulfur fixation rate under $4 \mathrm{wt} \%$ dosage.

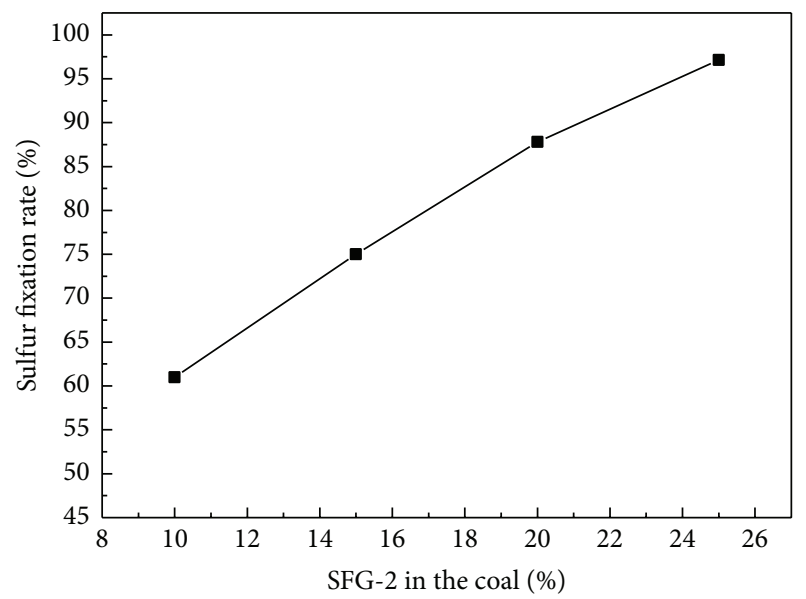

FIGURE 12: Effect of tricomponent composite SFG-2 on sulfur fixation rate under $20 \mathrm{wt} \%$ dosage.

3.6. XRD of Desulphurization Produced Ashes. The structural characteristic of desulphurization produced ashes was investigated by X-ray diffraction (XRD), and the analysis results of the produced ashes used SFG-2 as sulfur fixation agent at $950^{\circ} \mathrm{C}$ were shown in Figure 13. The diffraction structural peaks of $\mathrm{CaSO}_{4}, \mathrm{Fe}_{2} \mathrm{O}_{3}, \mathrm{Ca}_{2} \mathrm{Al}_{2} \mathrm{SiO}_{7}$, and $(\mathrm{Na}, \mathrm{Ca}) \mathrm{Al}(\mathrm{Si}, \mathrm{Al})_{3} \mathrm{O}_{8}$ could be clearly found, especially $\mathrm{CaSO}_{4}$, which showed that $\mathrm{CaSO}_{4}$ was the main component of sulfur fixation produced ashes at $950^{\circ} \mathrm{C}$ and the content is more. Besides, the existence of $\mathrm{Ca}_{2} \mathrm{Al}_{2} \mathrm{SiO}_{7}$ and $(\mathrm{Na}, \mathrm{Ca}) \mathrm{Al}(\mathrm{Si}, \mathrm{Al})_{3} \mathrm{O}_{8}$ also improved the sulfur fixation efficiency [32].

\section{Conclusion}

(1) The sulfur fixation rate of Bayer red mud could be improved by using fusel salt and waste mother liquor of sodium ferrocyanide as the modifying agents. When $50 \mathrm{wt} \%$ fusel salt solution was used as 


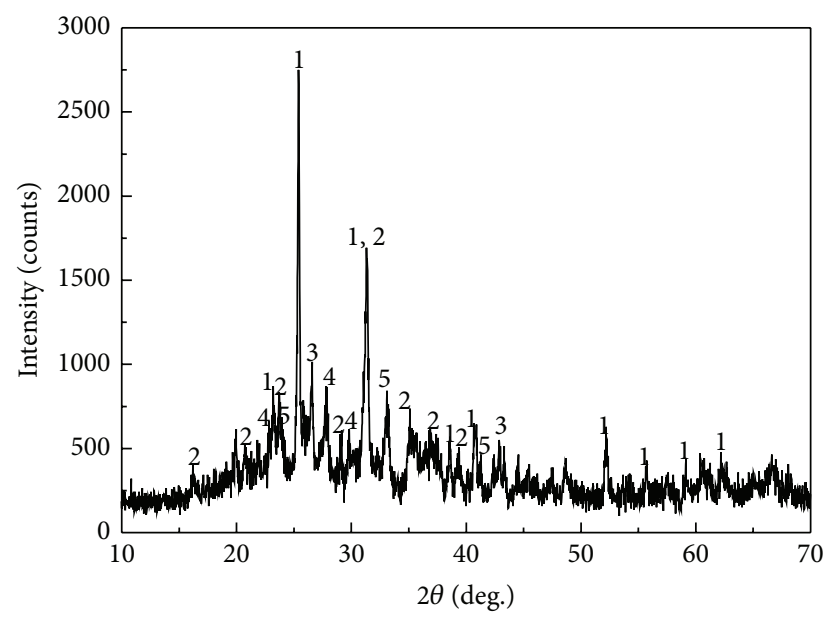

(1) $\mathrm{CaSO}_{4}$

(2) $\mathrm{Ca}_{2} \mathrm{Al}_{2} \mathrm{SiO}_{7}$

(3) $\mathrm{SiO}_{2}$

(4) $(\mathrm{Na}, \mathrm{Ca}) \mathrm{Al}(\mathrm{Si}, \mathrm{Al})_{3} \mathrm{O}_{8}$

(5) $\mathrm{Fe}_{2} \mathrm{O}_{3}$

FIGURE 13: XRD of sulfur fixation produced ashes.

modifying agent, the sulfur fixation rate increased by $7 \mathrm{wt} \%$ and the utilization rate of calcium increased from $22.02 \mathrm{wt} \%$ to $31.61 \mathrm{wt} \%$. When modified by waste mother liquor of sodium ferrocyanide with the concentration of $10 \mathrm{wt} \%$, sulfur fixation rate could increase by $13 \mathrm{wt} \%$, the highest of which could reach $29.85 \mathrm{wt} \%$ and the utilization rate of calcium reached $40.10 \mathrm{wt} \%$.

(2) Magnesium oxide ( $\mathrm{MgO})$ could obviously improve the sulfur fixation performance of Bayer red mud and up to a maximum sulfur fixation rate of $46.56 \mathrm{wt} \%$ with the 1 wt $\% \mathrm{MgO}$ adding.

(3) The sulfur fixation efficiency increased with the addition of the two natural mineral materials. Dolomite showed better effect than brucite. And the efficiency of sulfur fixation was different at $950^{\circ} \mathrm{C}$ with different dolomite/brucite ratio. With the dolomite increasing and brucite decreasing, the sulfur fixation increased. The sulfur fixation efficiency was $67.70 \mathrm{wt} \%$ when the sulfur fixation agent consisted of $10 \mathrm{wt} \%$ Bayer red mud and $4 \mathrm{wt} \%$ dolomite.

(4) Vermiculite dust could promote the fixed-sulfur efficiency. The main reasons were that further inflating of vermiculite dust at $950^{\circ} \mathrm{C}$ could make the inner looser and promote the inner oxidation extent of the coal combustion, which was advantageous to forming $\mathrm{CaSO}_{4}$ and restraining the decomposing of $\mathrm{CaSO}_{4}$.

(5) A new kind of tricomponent complex sulfur fixation agent SFG-2 was made successfully, in which modified Bayer red mud was the main desulphurization composition, dolomite served as additives, vermiculite dust played the inflation role, and the optimized mass ratio in order was $70: 28: 2$. The SFG-2 achieved desulphurization ration maximum $87 \mathrm{wt} \%$ when the doping content of SFG-2 in the coal was $20 \mathrm{wt} \%$ (i.e.,
$\mathrm{Ca} / \mathrm{S}$ mole ratio was 1.3 ), which indeed proved the advanced desulphurization characteristics of SFG-2.

\section{Competing Interests}

The authors declare that there is no conflict of interests regarding the publication of this paper.

\section{Authors' Contributions}

Yang Liu and Yang Li contributed equally to this work.

\section{Acknowledgments}

This research was supported by the National High Technology Research and Development Program of China (863 Program 2012AA06A109).

\section{References}

[1] J. Wang and H. M. Zhang, "Air pollution by sulfur dioxide and its control of coal fired industrial boilers in China," Electric Power Environmental Protection, vol. 20, pp. 43-46, 2004.

[2] H. M. Zhang and J. Wang, "Control of sulfur dioxide pollution from industrial coal fired boiler," Electric Power Environmental Protection, vol. 20, pp. 38-42, 2004.

[3] N. N. Zhang, Y. Jiang, and D. P. Xu, "The research status on sulfur solidifying technique during coal high-temperature combustion," Coal Quality Technology, vol. 24, no. 1, pp. 8-10, 2010.

[4] C. L. Chou, "Geologic characteristics of sulfur in coals and development of the clean coal technologies," Earth Science Frontiers, no. 1, pp. 23-27, 1999.

[5] B. Lin, Y. Z. Ge, and X. L. Zhang, "Introduction of fixedsulphur technology on calcium-based sorbents," Coal Chemical Industry, vol. 74, pp. 48-51, 1996.

[6] J. H. Li and A. H. Lu, "Effect of Ca-based mineral sulfur-fixing agent on sulfur retention of different kinds of coals," Techniques and Equipment for Environmental Pollution Control, vol. 7, pp. 36-40, 2006.

[7] Z.-S. Yuan, D.-Y. Wu, and S.-D. Wang, "Study on sulfur retention of integrated additive during coal combustion," Journal of Fuel Chemistry and Technology, vol. 30, no. 1, pp. 36-40, 2002.

[8] S.-L. Wang, "Influence of $\mathrm{CaO} / \mathrm{MgO}$ ratios on efficiency of sulfur fixation," Coal Geology \& Exploration, vol. 31, no. 2, pp. 4-7, 2003.

[9] N. Li, W. P. Liu, J. H. Zhou, and K. F. Cen, "Sulfur capture mechanism and application of novel barium-based sorbents at high temperature," Journal of Chemical Industry and Engineering (China), vol. 53, pp. 1198-1201, 2002.

[10] Z. H. Zhang and X. D. Ma, "Research status of sulfur-fixing agent," China Resources Comprehensive Utilization, vol. 27, pp. 13-14, 2009.

[11] P. Davini, G. DeMichele, and P. Ghetti, "An investigation of the influence of sodium chloride on the desulphurization properties of limestone," Fuel, vol. 71, no. 7, pp. 831-834, 1992.

[12] Y. Fu, G. Z. Lin, and Y. H. Zhuang, "On the role of sodium additives in desulfurization during coal briquette combustion," Environmental Chemistry, vol. 13, pp. 492-493, 1994. 
[13] L. R. Chen, L. M. Ge, and A. N. Zhou, "Study on modified calcium hydroxide with sodium alkali used as briquette capturing sulfur agent," Clean Coal Technology, vol. 11, pp. 73-75, 2005.

[14] K.-H. Han, J.-L. Zhao, B. Zheng, C.-M. Lu, and G.-J. Zhao, "Sulfur retention performance and modification of alkaline wastes used in coal combustion," Journal of the China Coal Society, vol. 34, no. 12, pp. 1698-1702, 2009.

[15] C. H. Dai and W. L. Zheng, "Catalytic sulfur retention of the transition-metal oxides under fluidized-bed combustion conditions," Coal Chemical Industry, vol. 38, no. 1, pp. 31-34, 2011.

[16] Z. H. Wu, P. Kou, Y. X. Shi, J. P. Zhang, and J. Wang, "Effects of alkali carbonates on the $\mathrm{CaO}$ desulfurization," Coal Conversion, vol. 23, pp. 59-62, 2000.

[17] X. Z. Gong, Z. C. Guo, and Z. Wang, "Reactivity of pulverized coals during combustion catalyzed by $\mathrm{CeO}_{2}$ and $\mathrm{Fe}_{2} \mathrm{O}_{3}$," Combustion and Flame, vol. 157, no. 2, pp. 351-356, 2010.

[18] Z. Z. Li and B. Q. Xiao, "Study of a newly high-temperatured compound sulfur fixztion agent for burning-coal," Science Technology and Engineering, vol. 7, pp. 3896-3902, 2007.

[19] G.-J. Zhao, C.-M. Lu, Y. Tian, Z.-Y. Fan, J.-L. Zhao, and Z.Y. Zhang, "Desulfurization characteristic and mechanism of red mud from alumina plant," Journal of Fuel Chemistry and Technology, vol. 36, no. 3, pp. 365-370, 2008.

[20] S. Wang, H. M. Ang, and M. O. Tadé, "Novel applications of red mud as coagulant, adsorbent and catalyst for environmentally benign processes," Chemosphere, vol. 72, no. 11, pp. 1621-1635, 2008.

[21] S. Z. Yu and R. L. Man, "Application of red mud in flue gas desulfurization from thermal power plant," Mining and Metallurgical Engneering, vol. 25, pp. 63-65, 2005.

[22] Y. N. Chen and J. X. Nie, "Adsorption of $\mathrm{SO}_{2}$ from flue gas with wastewater in red mud," Nonferrous Metals, vol. 59, pp. 153-155, 2007.

[23] X. Wang, X. H. Bao, and A. X. Zheng, "Study on the sulfur fixation of coal burning by red mud," Fly Ash Comprehensive Utilization, no. 6, pp. 23-25, 2010.

[24] H. T. Liu, K. H. Han, H. Li et al., "Sulfur retention performance of limestone modified by red mud for CFB boiler," Thermal Power Generation, vol. 41, no. 9, pp. 7-11, 2012.

[25] G. X. Yin, C. Ning, and X. F. Fu, "Development of sulfur fixation and combustion-supporting agent for loose coal using red mud and black liquor of papermaking," Environmental Engineering, vol. 22, no. 2, pp. 19-22, 2004.

[26] C. S. Lv, J. W. Wang, and C. Y. Lu, "The summary of the desulfurization process with Bayer red mud," Guangzhou Chemical Industry, vol. 40, pp. 20-22, 2012.

[27] R. K. Paramguru, P. C. Rath, and V. N. Misra, "Trends in red mud utilization-a review," Mineral Processing and Extractive Metallurgy Review, vol. 26, no. 1, pp. 1-29, 2005.

[28] Y.-C. Huang, N. Wang, J. Wan et al., "Comprehensive utilization of red mud and control techniques of radioactive issues," Bulletin of Mineralogy Petrology and Geochemistry, vol. 28, no. 2, pp. 128-130, 2009.

[29] H. N. Gu, N. Wang, and N. C. Zhang, "Study on radioactivity level of red mud and radiological constraints of usability as building materials," Light Metals, no. 5, pp. 19-21, 2011.

[30] "Methods for analysis and testing of coal and coke-ultimate analysis of coal and coke-determination of total sulfur content-eschka method," Tech. Rep. BS 1016-106.4.1-1993, British Standards Institution, 1993.
[31] China Coal Industry Association \& China National Standardization Management Committee, "Classification of quality of coal-part 2: sulfur content," Tech. Rep. GB/T 15224.2, China Standard Press, Beijing, China, 2010.

[32] K. Q. Wang and S. H. Li, "A study on occurrence mode of rare earth metals in red mud from Bayer process," Light Metals, no. 10, pp. 13-16, 2012.

[33] X. K. Wang, Y. H. Zhang, F. Z. Lv et al., "Removal of alkali in the red mud by $\mathrm{SO}_{2}$ and simulated flue gas under mild conditions," Environmental Progress \& Sustainable Energy, vol. 34, no. 1, pp. 81-87, 2015.

[34] H. Y. Qi, C. F. You, and A. J. Wang, "Influence of temperature on enhancing calcium conversion rate of sorbent and effects of steam reactivation," Journal of Engineering Thermophysics, vol. 24, pp. 717-719, 2003.

[35] G. J. Zhao, F. J. Yin, J. Li, and X. Y. Li, "Study on pore structure and sulfur fixation characteristics of alkali industrial waste," Advanced Materials Research, vol. 194-196, pp. 716-721, 2011.

[36] Y. Tan, Experiment research of additives on sulfur capture during coal combustion and analysis of mechanism on promoting effect [M.S. thesis], Hunan University, Hunan, China, 2005.

[37] M. Geng, L. Shi, and W. D. Xu, "Experimental research on using vermiculite as coal-burning sulfur-fixed additive," Non-Metallic Mines, vol. 29, pp. 28-30, 2006.

[38] J. H. Li, A. H. Lu, and C. X. Chen, "The application of vermiculite to the desulphurization and dusts clearing during coal combustion," Acta Petrologica et Mineralogica, vol. 20, pp. 515-524, 2001. 

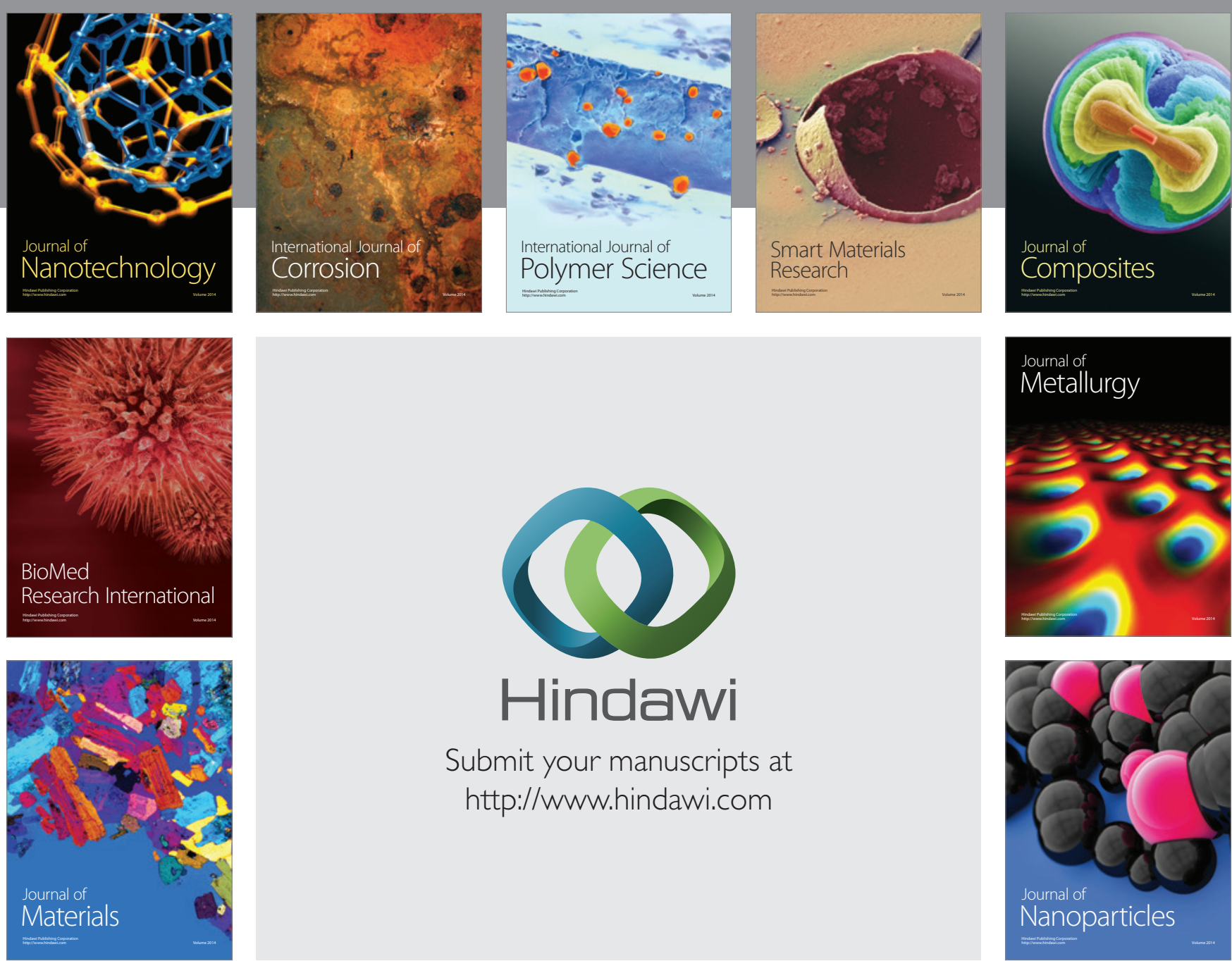

\section{Hindawi}

Submit your manuscripts at

http://www.hindawi.com

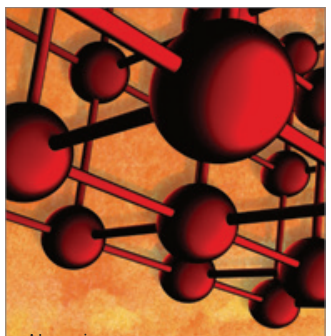

Materials Science and Engineering
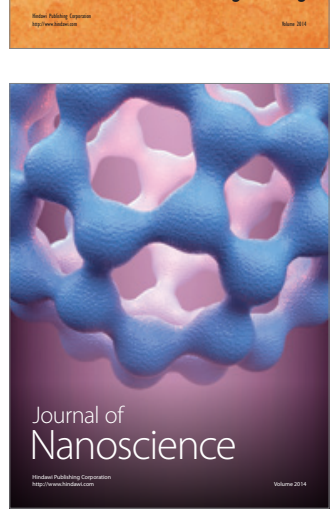
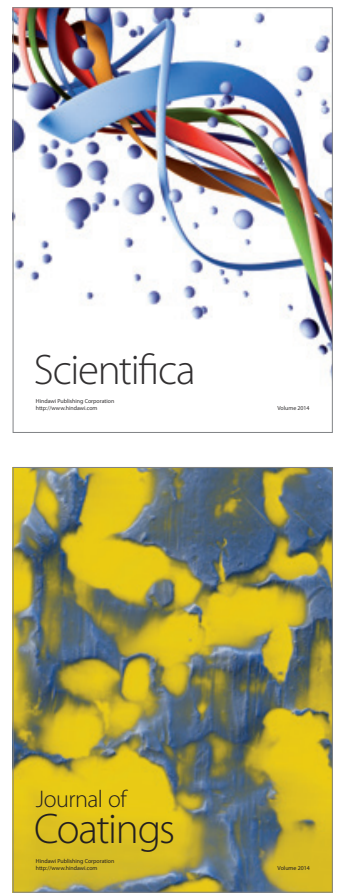
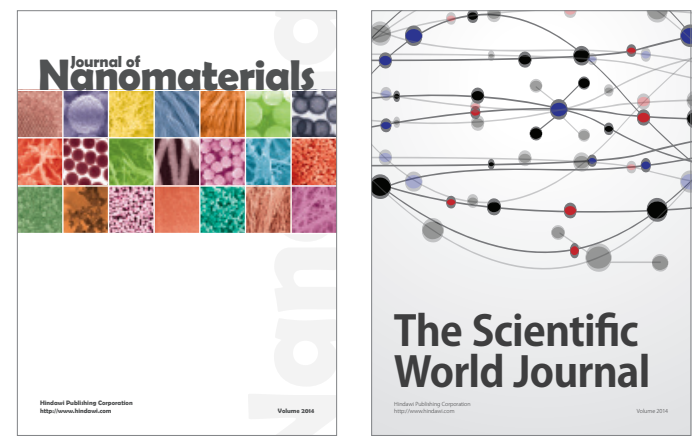

The Scientific World Journal
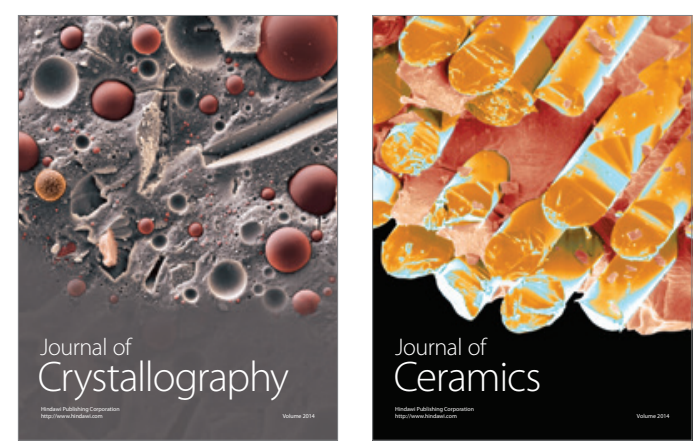
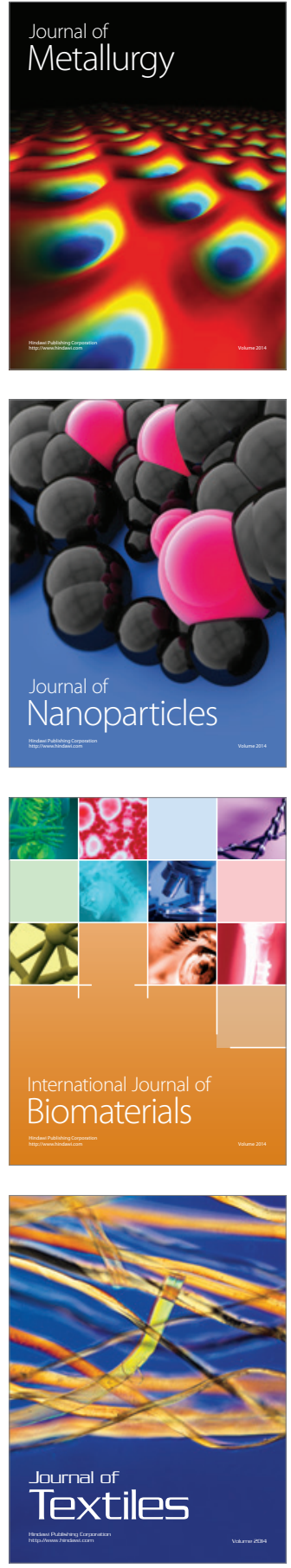